\title{
ANALYSIS OF FACTORS THAT INFLUENCE THE COMPLIANCE OF TAX AND RESTAURANT TAXES IN TABANAN REGENCY OF BALI, INDONESIA
}

\author{
Wirawati Ni Gusti Putu*, Putra I Nyoman Wijana Asmara \\ Faculty of Economic and Business, University of Udayana, Bali, Indonesia \\ *E-mail: ngpwirawati@unud.ac.id
}

\begin{abstract}
This study aims to examine the effect of service quality, enforcement of tax sanctions, distributive justice and moral obligations of hotel and restaurant taxpayers on tax compliance. The study was conducted in Tabanan Regency, Bali, Indonesia with respondents to the owners or general managers of hotels and restaurants. The method of determining the sample with probability sampling using proportional stratified random sampling technique. So that 65 respondents were obtained. The source of research data is primary data collected by the method of Data analysis technique used is multiple linear regression. The analysis shows that distributive justice has a positive effect on hotel and restaurant taxpayer compliance, service quality has a positive effect, while enforcement of tax sanctions and moral obligations has no effect on hotel and restaurant taxpayer compliance in Tabanan Regency.
\end{abstract}

\section{KEY WORDS}

Tax, quality, sanctions, distributive justice.

Regional autonomy opens opportunities to increase regional independence. Regions are given the authority to regulate and manage their own government affairs, including exploring the broadest potential of Local Revenue (PAD). Regional Original Income (PAD) is regional income derived from regional taxes, regional levies, separated regional wealth management, and other legitimate local revenue, which aims to provide flexibility to the region in exploring funding for the implementation of regional autonomy as embodied the principle of decentralization.

In general, taxes are defined as levies from the state to the people, which are compelling. Taxes are used to finance government expenditures including financing for development that is useful for mutual interests. Taxes cannot be separated from government; this is because taxes are an element of the implementation of government functions. Tax is one way to divert wealth from the private sector to the public sector needed to carry out government functions. Hotel and restaurant taxes can be classified as indirect taxes, where the tax is based on the services provided to these consumers, the burden is on consumers. The hotel and restaurant owner / entrepreneur are the party who collects and deposits the tax yield to the agency which authorized to receive the tax collection.

Regional taxes must also have a legal basis so that these levies can be forced. As with the central tax, regional taxes also have an element of coercion in their collection so that a legal basis is needed. However, the regional tax can be applied using a legal basis in the form of regional regulations. Hotel and Restaurant Taxes (PHR) include elements of Regional Tax which contribute to Locally-generated revenue (PAD).

The large contribution of hotel and restaurant taxes also occurred in Tabanan Regency. This is confirmed by the fact that the plan to build a hotel by the President of the United States, Donald Trump in the Pan Pacific Nirwana Bali Resort area, Tanah Lot, could directly threaten the finances of Tabanan's Government. That is because the development that is likely to be carried out for three years automatically eliminates hotel and restaurant taxes, whose annual value reaches Rp. 31 billion. (Tribun-Bali.com). Based on the results of hotel and restaurant tax audits, it shows that taxpayers are still found.

Compliance with hotel and restaurant taxpayers in Tabanan Regency is governed by Law No. 28 of 2009 concerning Regional Taxes and Regional Levy. The law stipulates that regional taxes are the contribution of taxpayers to regions that are forced by not receiving 
direct compensation for regional needs and prosperity of the people. This provision confirms that hotel and restaurant taxpayers in Tabanan Regency must fulfill their tax obligations. Based on the background of the problem which is the main problem is what factors influence the compliance of hotel and restaurant taxpayers in Tabanan Regency?

Non-compliance of taxpayers can be caused by the absence of direct incentives felt by taxpayers or the existence of taxpayer dissatisfaction with public services. (Manurung, 2013) states that non-compliance of taxpayers in paying taxes can also be caused by tax penalties that are still mild. Compliance with compulsory hotel and restaurant tax is very important for the receipt of PAD. If taxpayer compliance does not increase, it can threaten regional revenues and threaten government efforts to improve people's welfare (Chau and leung. 2009, Faudi, 2013). A sense of justice for taxpayers can also affect taxpayer compliance. Quality of service is also very meaningful for taxpayers. Enforcement of sanctions can create tax compliance and is considered an effective policy to prevent non-compliance of taxpayers. Motivation from within the taxpayer is also very important, especially the moral obligations possessed by taxpayers. Based on the description, the purpose of the research specific research is as follows:

- provide empirical evidence of the effect of distributive justice on taxpayer compliance;

- provide empirical evidence of the effect of service quality on tax compliance;

- provide empirical evidence of the effect of sanction enforcement on tax compliance;

- provide empirical evidence of the effect of moral obligations on taxpayer compliance.

The obligation of hotel entrepreneurs to pay hotel taxes is regulated by the Regional Regulations of Tabanan Regency Number 24 Year 2011 About Hotel Taxes and regional regulations Number 23 of 2011 regulating restaurant taxes. In the regulation it is stated that an individual or entity buys food and / or drinks in a restaurant. The Hotel Tax subject is an individual or entity that makes payments to individuals or agencies that seek hotels. This regulation confirms that hotel and restaurant taxpayers in Tabanan Regency must fulfill their tax obligations.

\section{LITERATURE REVIEW}

This study analyzes the factors that influence the compliance of hotel and restaurant taxpayers in fulfilling their tax obligations. Compliance with hotel and restaurant taxpayers for their tax obligations, in this study, viewed from two perspectives, namely from taxpayer external factors, namely perceptions of distributive justice, service quality and tax sanctions. While internal factors of taxpayers are a moral obligation. This study uses attribution theory and compliance theory as the theoretical basis.

Attribution theory studies the process of someone interpreting an event and learning how someone interprets the reason or cause of his behavior (Suartana, 2010). Attribution theory views individuals as amateur psychologists who try to understand the causes that occur in the various events they face. This theory tries to find out what causes what, or what drives who does what. The response given to an event depends on our interpretation of the event (Kelly, 1972, 1973).

Attribution theory states that individual behavior can arise internally and externally (Robbins, 2008). Behavior caused internally is believed to be under the individual's own control or comes from internal factors such as personality traits, awareness and abilities. This is referred to as internal attribution. Behavior caused by individual external factors is influenced by external factors such as equipment or social influences from others. This means that the individual is forced to behave in a situation, this is an external attribution.

Attribution theory is used in taxpayer compliance research related to the attitude of taxpayers in assessing tax obligations that must be done. Attribution theory states that related to one's behavior, individuals will try to classify the behavior caused by internal or external influences (Robbins, 2008).

Compliance comes from obedient words, according to the Indonesian General Dictionary, obedient means to like and obey orders or rules, and be disciplined. Compliance means obedience, obedience, submission to teachings or rules. Compliance with a system of 
rules has a consequence on social interactions that run well, without the possibility of changing into open or veiled conflicts in chronic conditions (Ardani, 2010).

Compliance is the motivation of a person, group or organization to act or not in accordance with established rules. A person's obedient behavior is the interaction of the behavior of individuals, groups and organizations. Compliance is divided into two (OECD, 2001), namely:

- Administrative compliance is compliance with administrative rules such as timely payments, definitions contained in administrative compliance including reporting requirements, procedural compliance or compliance with regulations;

- Technical compliance, namely compliance with tax calculations in accordance with technical tax law or taxpayers pay the tax portion that they must pay in accordance with the provisions of the law.

Compliance with taxpayers is compliance with calculations, deposits and tax reporting. Distributive Justice. Ulupui (2005) states distributive justice is related to outcomes because the emphasis is on distribution received without considering how the distribution is done. This study explains distributive justice in the variable taxpayer compliance. Tjahyono's research (2008) revealed that distributive justice is more dominant in influencing individual satisfaction, because individuals have attention and interest in the location of goods and services for their welfare, so that the local government through the Dispenda needs to review the tax payment allocation aspects with general development.

Service quality is a comparison between what the customer wants about their assessment of the actual performance of a service provision. Tjiptono (2002: 70), states that there are five dimensions to evaluate the quality of services, namely:

- Physical evidence (tangibles), is a physical facility, employee, equipment and communication;

- Reliability, is the ability of officers to provide services that promise promptly and satisfactorily;

- Responsiveness is a characteristic of compatibility in human services, namely the desire of tax officials to assist taxpayers and provide responsive services;

- Assurance, which includes the ability, politeness and trustworthiness of the tax officer free from risk, danger, or doubt;

- Empathy, which includes the ease of officers in making good communication relationships and understanding taxpayers.

Taxation sanctions are a guarantee that the provisions of taxation laws (norms of taxation) will be obeyed (Mardiasmo, 2011: 47). In the tax law there are two kinds of sanctions, namely:

- Administrative sanctions, are payments for losses to the State, especially in the form of fines, interest, and increases;

- Criminal sanctions are a final tool or legal bastion used by tax authorities to comply with tax norms, in the form of criminal fines, confinement, and imprisonment.

Ajzen (2002) states that moral obligation is moral that comes from each individual, which is likely that other people do not have it. The moral aspect in the taxation field concerns two things, namely (1) tax obligations are moral obligations that must be prioritized by each taxpayer, and (2) concerning moral awareness related to the allocation or distribution of tax revenues (Troutman, 1993).

This study refers to several previous studies as a reference. Albari (2008) examined the effect of justice on taxpayer satisfaction and compliance. This study successfully proved the direct and indirect positive influence of justice on taxpayer compliance through a variable between satisfactions. One dimension of justice in this study is interactional justice which partially has no significant effect on taxpayer compliance.

The effect of distributive justice and sanction enforcement on the level of hotel and restaurant taxpayer compliance with taxpayer satisfaction as moderating, in Tabanan Regency was tested by Budhiarsana (2015. This study found that distributive justice, enforcement of sanctions and satisfaction of taxpayers partially had a positive effect on 
mandatory compliance hotel and restaurant tax. The satisfaction of taxpayers strengthens the effect of enforcing sanctions on hotel and restaurant taxpayer compliance. Although taxpayer satisfaction directly affects taxpayer compliance, taxpayer satisfaction does not strengthen the influence of distributive justice on hotel and restaurant taxpayer compliance.

Sukarma (2015), examined the locus of control as moderating the effect of service quality and tax sanctions on compulsory compliance with rural and urban land and building tax in Tabanan Regency. The results of this study show a positive influence on service quality and tax sanctions on the compliance of PBB-P2 tax credit, while local of control does not strengthen the influence of service quality on PBB-P2 tax compliance.

The influence of understanding taxation, service quality, firmness of tax sanctions and tax audit on tax compliance with the level of education as a moderator (Harmawati (2015) This study was conducted in the State District with compulsory land and urban taxpayers and urban respondents. The results of this study showed a positive effect understanding of taxation, service quality, firmness of tax sanctions and tax audit on PBB-P2 compulsory tax compliance. The results of the study also show that the level of education is able to moderate the influence of understanding taxation and the firmness of tax sanctions, but the level of education is not able to moderate service quality and tax audit on compliance taxpayer.

Factors influencing taxpayer compliance pay hotel tax, restaurant tax and entertainment tax in Denpasar City (Trisnawati (2015). The results of the study show the effect of tax, service quality and tax audit have a positive effect on the awareness of paying taxpayers and have a positive effect on hotel taxpayer compliance, customer tax and entertainment tax in Denpasar City Knowledge of tax, service quality, and tax audit has significant indirect effect on taxpayer compliance through awareness of taxpayers paying hotel tax, restaurant tax and entertainment tax in Denpasar City. taxpayers partially mediate the effect of tax, service quality, and tax audit on tax compliance.

Jatmiko (2006) examined the effect of taxpayer attitudes on the implementation of fines, tax services and tax awareness of taxpayer compliance. This study found that the attitude of taxpayers to the implementation of witnesses' fines, attitudes of taxpayers on fiscal services and attitudes of taxpayers to tax awareness had a significant positive effect on tax compliance.

Factors influencing hotel taxpayer compliance in making hotel tax payments were tested by Sanjaya (2014). From the results of research and discussion, it can be concluded that service quality, moral obligations, and tax sanctions partially have a positive and statistically significant effect on taxpayer compliance in paying hotel taxes in the Denpasar City Revenue Service.

Layata (2014) examined the effect of moral obligations, service quality and tax sanctions on corporate taxpayer compliance at South Badung Primary Tax Office. Moral obligation has a positive effect on corporate taxpayer compliance in KPP Pratama South Badung, Service Quality of KPP Pratama South Badung has a positive effect on corporate taxpayer compliance at KPP Pratama Selatan Badungf and tax sanctions have a positive effect on corporate taxpayer compliance at South Badung KPP.

The difference between this research and previous research is that this research was conducted in Tabanan Regency. This study measures the variable taxpayer compliance using documentation techniques, while the independent variables are measured using questionnaire techniques. The respondent is the owner (owner) or General Manager of hotel and restaurant taxpayers.

Based on the results of previous studies, the research hypothesis is as follows.

H1: Distributive justice has a positive effect on hotel and restaurant taxpayer compliance;

H2: Service quality has a positive effect on hotel and restaurant taxpayer compliance;

H3: Enforcement sanctions have a positive effect on hotel and restaurant taxpayer compliance;

H4: Moral Obligations have a positive effect on hotel and restaurant taxpayer compliance. 


\section{METHODS OF RESEARCH}

This research was conducted in Tabanan Regency, Bali. The research subjects were hotel and restaurant taxpayers (WP PHR). The variables studied were as follows:

- Compliance with taxpayers is compliance with rules and technical compliance. Compliance indicators are timely tax reporting, namely deposits (Regional Tax Returns-SPTPD) no later than the 15th of the following month. Timely depositing the Regional Tax-SSPD Deposit Letter no later than the 20th of the following month;

- Distributive justice is the level of feasibility of the end result of the activities perceived by customers from their complaints; although that does not mean that they have to be profitable or unfavorable to the customer. Indicator of distributive justice is justice in paying taxes;

- Service Quality is the taxpayer's perception of the comparison between desired expectations and their assessment of the actual performance of a service provider. Indicators of service quality are physical condition, reliability, responsiveness, assurance and empathy;

- Enforcement of sanctions is a guarantee that the provisions of tax laws and regulations (taxation norms) will be obeyed;

- Moral Obligation is the principle of life, feeling guilty if it does not carry out voluntary tax obligations that can be associated with fulfilling tax obligations, especially hotel and restaurant taxpayers.

The type of data used is quantitative data, namely data in the form of numbers or qualitative data that are predicted. The quantitative data in this study were the number of WP PHR registered in Taban Regency and the respondent's answer to the questionnaire was measured by a Likert scale.

Data sources are primary data and secondary data. Primary data is data obtained directly from the results of the respondent's answer to the statement in the questionnaire factors that influence the compliance of WP PHR. Sampling is done by Proportional Stratified Random Sampling technique. The method used to determine the number of samples is slovin formula.

The data in this study were tested using multiple linear regression. Before being used to test hypotheses, classical assumptions were tested first. Classic assumption test includes normality test, multicollinearity and heteroscedasticity test. The regression model used is as follows:

$$
Y=\alpha+\beta_{1} X 1+\beta_{2} X 2+\beta_{1} X 3+\beta_{2} X 4+\varepsilon
$$

Where $\alpha$ : constant, X1: Distributive Justice, X2: Service Quality, X3; Enforcement of Tax Sanctions, X4: Moral Obligations, Y: Taxpayer Compliance, $\beta$ : Regression coefficient, $\varepsilon$ : Error.

The research hypothesis is accepted if the probability value ( $P$-Value) $t$ is smaller or equal to 0.05 (5 percent).

\section{RESULTS AND DISCUSSION}

Respondents used in this study are the owners (owners) of hotels and restaurants in Tabanan regency. For hotels and restaurants whose ownership is determined by the number of shares owned, then the respondent is the general manager. This study uses Proportional Stratified Random Sampling, namely the number of Hotel and Restaurant Taxpayers determined by proportion. The number of respondents who were asked to fill out the questionnaire was 65 respondents. The questionnaire was distributed in April 2018 until June 2018. The questionnaire was delivered directly to each hotel and restaurant determined randomly. Sixty-five questionnaires distributed all returned with complete answers. The sample profile in this study is shown in Table 1. 
Table 1 - Sample Profile

\begin{tabular}{lccc}
\hline & Category & Amount & Percentage (\%) \\
\hline Hotel Bintang & & 2 & 3,80 \\
Hotel Melati / Pondok wisata & 43 & 66,15 \\
Restaurant & Amount & 20 & 30,05 \\
\cline { 3 - 4 } & Amo & 65 & 100 \\
\hline
\end{tabular}

Table 1 shows that of the 65 samples used in the study, as many as 3.80 percent were starred hotels, 43 samples were budget hotels / tourist hotels and as many as 30.05 percent were in the category of restaurants. The profile of 65 respondents by sex, education level and position is shown in Table 2.

Table 2 - Respondents Profile

\begin{tabular}{|c|c|c|}
\hline Descriptions & Amount & Percentage (\%) \\
\hline Gender & & \\
\hline Male & 50 & 76,92 \\
\hline Female & 15 & 23,08 \\
\hline Amount & 65 & 100 \\
\hline \multicolumn{3}{|l|}{ Last Education } \\
\hline Graduate (S2) & 1 & 1,50 \\
\hline Undergraduate (S1) & 10 & 15,38 \\
\hline Diploma & 30 & 46,15 \\
\hline Others & 24 & 36,97 \\
\hline Amount & 65 & 100 \\
\hline \multicolumn{3}{|l|}{ Position } \\
\hline Owner & 55 & 84.61 \\
\hline General Manager & 10 & 15,39 \\
\hline Amount & 65 & 100 \\
\hline
\end{tabular}

Based on Table 2, it can be seen that of the 65 respondents, 50 were men and 15 were women. Judging from the level of education, there are 1 master, 10 undergraduate students, 30 diploma students and 24 other senior high school and vocational high school students. 55 direct owner managers and 10 general managers.

Before being disseminated the research instruments were tested using validity test and reliability test with respondents in testing the instrument were 30 undergraduate students of the Faculty of Economics and Business, Udayana University. Validity test serves to measure the validity or not the questions in the questionnaire. Validity test is used by testing the correlation between the scores of each question item and the total score of the questionnaire. A questionnaire is said to be valid if the correlation coefficient between the scores where the correlation must be positive and is $>0.3$ and significant at 0.05 . From Statistical Package for the Social Sciences (SPSS) calculations, the results of each variable are valid because they show a correlation value of $>0.3$ and a significance level of $<0.05$.

The reliability test results show that the value of Cronbach's Alpha distributive justice variable $=0.844$, service quality $=0.902$, enforcement of tax sanctions $=0.804$, and moral obligation $=0.807$. All of these values are greater than 0.6 so it can be concluded that all questions related to this research variable are reliable. The results of the validity and reliability tests are presented in Table 3 below.

Descriptive statistics are presented in providing information about the characteristics of the research variables. A summary of the results of descriptive statistics can be seen in Table 4.

Regression analysis using Ordinary Least Square (OLS) techniques requires a classical assumption test. The classic assumption test that will be carried out in this study is the test for normality, multicollinearity, and heteroscedasticity. This test is conducted to obtain the confidence that the regression model obtained has the ability to predict in decision making. The normality test is carried out using the Kolmogorov-Smirnov test. The results of the normality test indicate that Asymp. Sig. (2-tailed) in the One-Sample KolmogorovSmirnov Test is 0.200 . This value is greater than the significance of 0.05 , so the data tested 
is normally distributed. Heteroscedasticity test aims to find out whether in the regression model variance of the residuals occurs in an observation to another observation (Ghozali, 2013). Heteroscedasticity testing is done using the Glejser test, namely by regression of the absolute residual value of the model estimated on the independent variable. Test results show that none of the independent variables have a significant effect on the absolute residual dependent variable. The multicolourity test aims to test whether the regression model found a correlation between independent variables. A good model does not have a correlation between independent variables. The results of the multicollinearity test show that the four independent variables have tolerance values $>0.10$ and the Variance Inflation Factor (VIF) value $<10$. This indicates that this regression equation meets the multicollinearity test requirements.

Table 3 - Validity and Reliability Test Results

\begin{tabular}{|c|c|c|c|c|}
\hline \multirow{2}{*}{ Variable } & \multirow{2}{*}{ Indicator } & \multicolumn{2}{|l|}{ Validity Test } & \multirow{2}{*}{$\begin{array}{l}\text { Reliability Test } \\
\text { Cronbach's Alpha }\end{array}$} \\
\hline & & Correlation Coefficient $(r)$ & Sig. & \\
\hline \multirow{7}{*}{ Distributive Justice $\left(X_{1}\right)$} & $\mathrm{X}_{1.1}$ & 0,881 & 0,000 & \multirow{7}{*}{0,844} \\
\hline & $X_{1.2}$ & 0,714 & 0,000 & \\
\hline & $\mathrm{X}_{1.3}$ & 0,836 & 0,000 & \\
\hline & $\mathrm{X}_{1.4}$ & 0,653 & 0,000 & \\
\hline & $X_{1.5}$ & 0,858 & 0,000 & \\
\hline & $X_{2.1}$ & 0,808 & 0,000 & \\
\hline & $X_{2.2}$ & 0,790 & 0,000 & \\
\hline \multirow{4}{*}{ Service Quality $\left(\mathrm{X}_{2}\right)$} & $\mathrm{X}_{2.3}$ & 0,750 & 0,000 & \multirow{6}{*}{0,902} \\
\hline & $X_{2.4}$ & 0,836 & 0,000 & \\
\hline & $\mathrm{X}_{2.5}$ & 0,719 & 0,000 & \\
\hline & $X_{2.6}$ & 0,760 & 0,000 & \\
\hline \multirow{5}{*}{ Enforcement of Tax Sanctions $\left(X_{3}\right)$} & $\mathrm{X}_{2.7}$ & 0,701 & 0,000 & \\
\hline & $\mathrm{X}_{2.8}$ & 0,824 & 0,000 & \\
\hline & $X_{3.1}$ & 0,763 & 0,000 & \multirow{3}{*}{0,804} \\
\hline & $X_{3.2}$ & 0,824 & 0,000 & \\
\hline & $X_{3.3}$ & 0,852 & 0,000 & \\
\hline \multirow{5}{*}{ Moral Obligation $\left(\mathrm{X}_{4}\right)$} & $X_{3.4}$ & 0,732 & 0,000 & \multirow{5}{*}{0,807} \\
\hline & $X_{4.1}$ & 0,741 & 0,000 & \\
\hline & $X_{4.2}$ & 0,836 & 0,000 & \\
\hline & $X_{4.3}$ & 0,876 & 0,000 & \\
\hline & $X_{4.4}$ & 0,723 & 0,000 & \\
\hline
\end{tabular}

Table 4 - Descriptive Statistic Test Results

\begin{tabular}{c|c|c|c|c|c}
\hline Variable & $\mathrm{N}$ & Minimum & Maximum & Mean & Std. Deviation \\
\hline Distributive Justice $\left(\mathrm{X}_{1}\right)$ & 65 & 11,00 & 20,00 & 17,569 & 2,7441 \\
Service Quality $\left(\mathrm{X}_{2}\right)$ & 65 & 17,00 & 32,00 & 27,507 & 4,0701 \\
Enforcement of Tax Sanction $\left(\mathrm{X}_{3}\right)$ & 65 & 8,00 & 16,00 & 13,646 & 2,1023 \\
Moral Obligation $\left(\mathrm{X}_{4}\right)$ & 65 & 8,00 & 16,00 & 13,584 & 2,0531 \\
Taxpayer Compliance $(\mathrm{Y})$ & 65 & 1,00 & 16,00 & 12,446 & 4,6031 \\
\hline
\end{tabular}

The $t$ test is used to show the effect of independent variables on variations in the dependent variable individually. The $t$ test is done by comparing the results of the $p$-value significance value of the influence of the independent variable and interaction of variables on the dependent variable with $\alpha=0.05$. If the $p$-value is smaller equal to $\alpha=0.05$ then the independent variable has an effect on the dependent variable and vice versa if the $p$-value is greater equal to $\alpha=0.05$, then the independent variable has no effect on the dependent variable.

The results of multiple regression analysis with the help of the SPSS program ver.22 for windows show that the four independent variables of distributive justice, service quality, enforcement of tax sanctions and moral obligations each influence the compliance of hotel and restaurant taxpayers. The full results are shown in Table 5. 
Table 5 - Multiple Regression Analysis Results

\begin{tabular}{|c|c|c|c|c|c|}
\hline \multirow{2}{*}{ Variable } & \multicolumn{2}{|c|}{ Unstandardized Coefficients } & \multirow{2}{*}{$\begin{array}{c}\text { Standardized Coefficients } \\
\text { Beta }\end{array}$} & \multirow{2}{*}{$\mathrm{t}$} & \multirow{2}{*}{ Sig. } \\
\hline & $\beta$ & Std. Error & & & \\
\hline (Constant) & $-13,792$ & 3,118 & & $-4,423$ & 0,000 \\
\hline Distributive Justice (X1) & 0,440 & 0,216 & 0,262 & 2,035 & 0,046 \\
\hline Quality Service (X2) & 0,297 & 0,147 & 0,262 & 2,014 & 0,048 \\
\hline Enforcement of Tax Sanction (X3) & 0,429 & 0,278 & 0,196 & 1,546 & 0,127 \\
\hline Moral Obligation (X4) & 0,330 & 0,275 & 0,147 & 1,200 & 0,235 \\
\hline Adjusted $\mathrm{R}^{2}$ & \multicolumn{5}{|c|}{0.519} \\
\hline $\mathrm{F}$ test & & & 8,289 & & 0.000 \\
\hline
\end{tabular}

Based on Table 5, we can summarize the regression equation model of the influence of distributive justice, service quality, enforcement of tax sanctions and moral obligations on tax compliance as follows:

$$
Y=-3,792+0,440 X_{1}+0,297 X_{2}+0,429 X_{3}+0,330 X_{4}
$$

Based on Table 5, the regression test results obtained partial effects of independent variables of distributive justice, service quality, enforcement of tax sanctions, and moral obligations on tax compliance with the following details:

- Regression test of distributive justice variables on taxpayer compliance is obtained $\beta$ $=0.440$ with $p$-value of 0.046 which is smaller than $\alpha=0.05$. This means that distributive justice has a positive effect on tax compliance. Thus the results of this hypothesis test accept the $\mathrm{H} 1$ hypothesis which states that distributive justice has a positive effect on tax compliance;

- Test regression variable service quality on taxpayer compliance obtained $\beta$ coefficient $=0.0297$ with $p$-value of 0.048 which is smaller than $\alpha=0.05$. This means that service quality has a positive effect on tax compliance. Thus the results of this hypothesis test accept the $\mathrm{H} 2$ hypothesis which states that service quality has a positive effect on taxpayer compliance;

- Test the regression of tax sanction enforcement variables on taxpayer compliance obtained $\beta$ coefficient $=0.429$ with $p$-value of 0.127 which is greater than $\alpha=0.05$. This means that enforcement of tax sanctions does not have a significant effect on tax compliance. Thus the results of this hypothesis test reject the H3 hypothesis which states that enforcement of tax sanctions has a positive effect on taxpayer compliance;

- Test the regression of moral obligation variables on taxpayer compliance obtained $\beta$ coefficient $=0.330$ with $p$-value of 0.235 which is smaller than $\alpha=0.05$. This means that moral obligations have no significant effect on tax compliance. Thus the results of this hypothesis test reject the $\mathrm{H} 4$ hypothesis which states that moral obligations have a positive effect on taxpayer compliance.

\section{DISCUSSION OF RESULTS}

The one hypothesis states that distributive justice has a positive effect on hotel and restaurant taxpayer compliance in Tabanan district. The results of the analysis show that distributive justice has a positive effect on tax compliance. This result implies that the higher distributive justice felt by taxpayers, will tend to encourage hotel and restaurant taxpayers to comply with their tax obligations.

This result shows that the general manager and hotel and restaurant owners as respondents supported by their educational backgrounds have very good perceptions of the fairness of the hotel and restaurant tax system and the utilization of hotel and restaurant taxes conducted by the Tabanan Regency Government. The existence of a very good perception is able to increase their obedient behavior in carrying out hotel and restaurant tax obligations in accordance with applicable regulations. 
This result is in accordance with attribution theory which states that individual obedient behavior is supported by internal factors. In this study distributive justice is felt by hotel and restaurant taxpayers. This finding supports the study of Albari (2008) who found distributive justice to have an effect on tax compliance. These results also support the results of the study by Budhiarsana (2015). Based on the theoretical study of the theory of attribution which states that the behavior shown by a person can be caused by external factors, namely behavior influenced from the outside. External factors can be in the form of distributive justice given by the regional government. Taxpayers who are treated fairly by the government even though they will not directly feel happy and valued so they tend to increase compliance. These results support the theory of justice proposed by Robbins (2008) which states that individuals compare the input and results of their work with the input and results of the work of others and then respond to eliminate injustice. Distributive justice perceived by taxpayers encourages taxpayer compliance.

The second hypothesis states that service quality has a positive effect on hotel and restaurant taxpayer compliance in Tabanan Regency. The results of the analysis show that service quality has a positive effect on taxpayer compliance. These results imply that the better the quality of service received by taxpayers, will tend to encourage hotel and restaurant taxpayers to comply with the obligation to pay taxes. This finding supports the research by Sukarma (2015) who found service quality had an effect on tax compliance. This result also supports the research results of Harmawati (2015) and Trisnawati (2015).

Attribution theory which states the behavior shown by a person can be caused by external factors, namely behavior that is influenced from the outside. External factors can be in the form of services provided by tax officials. Taxpayers who get good quality services will feel happy and facilitated and helped in completing their obligations. Service quality which is an external factor of taxpayers can encourage tax compliance. Five dimensions to evaluate the quality of services, namely tangibles, reliability, responsiveness, assurance, and empathy.

Physical evidence includes facilities, employees, equipment and communication. Special services for hotel and restaurant tax are incorporated in the Tabanan Regency Revenue Service. The amount of taxpayers who carry out obligations requires a waiting room and a large parking lot so that taxpayers feel comfortable. In addition, sufficient numbers of employees and computer equipment are needed so that services can run faster. Reliability is the ability of tax officers to provide services that promise immediately and satisfactorily. The Tabanan Regency Revenue Service in the process of completing hotel and restaurant tax services takes 5 to 10 minutes from reporting to payment of hotel and restaurant taxes. For hotel and restaurant taxpayers who are barred from coming to the Tabanan Regency Revenue Service, they can ask tax officers both data officers and collectors to help take and process their tax obligations to taxpayers. Responsiveness is a characteristic of compatibility in human services, namely the desire of tax officials to help taxpayers and provide responsive services. In the Tabanan Regency Revenue Service, there is a section that handles complaints and problems with hotel and restaurant taxpayers.

Guarantees include the ability, politeness and trustworthiness of the tax officer. The Tabanan Regency Revenue Service in providing guarantees to taxpayers continues to improve both from going to online tax payments to all hotel and restaurant taxpayers to provide study permits and study assignments for tax officers. Empathy is related to the ease of officers in making good communication so that taxpayers will feel cared for.

The third hypothesis states that enforcement of tax sanctions has a positive effect on hotel and restaurant taxpayer compliance in Tabanan Regency. The results of the analysis show that the enforcement of tax sanctions does not affect taxpayer compliance. This result implies that the perception of hotel and restaurant taxpayers regarding the determination and application of hotel and restaurant tax sanctions by the Tabanan Regency Government does not cause hotel and restaurant taxpayer compliance to be more obedient in carry out its obligations.

These results indicate that even though hotel and restaurant general managers and owners as respondents on average state enforcement of strict sanctions, they tend to feel 
that implementation of sanctions by tax officials is not timely, a 2 percent interest penalty tends to be mild. The tendency of these perceptions is not able to increase their obedient behavior in carrying out hotel and restaurant tax obligations in accordance with applicable regulations.

These results do not support the Attribution theory. Based on Attribution theory, enforcing tax sanctions is an external factor that can affect taxpayer behavior. The enforcement of strict tax sanctions will make taxpayers forced to behave obediently because of the situation. Taxpayers will fulfill their tax obligations by considering the administration of interest (interest, penalties and increases) given to the taxpayer's financial burden in paying off his tax obligations.

The results of this study are not consistent with the Sukarma study (2015) which concluded that there was a positive influence between tax sanctions and compulsory compliance with Rural and Urban Land and Building tax in Tabanan Regency. The results of this study support the results of research from Harmawati (2015), Budhiarsana (2015), Sanjaya (2014), Layata (2014) and Jatmikon (2014) who found a positive effect of taxation sanctions on taxpayer compliance.

Explained in the Act and regulations outline contains rights and obligations, actions that are permitted and not permitted by the community. In order for these laws and regulations to be obeyed, there must be sanctions for violators, as well as for tax law. Enforcement of tax sanctions is needed to provide a deterrent effect for violators, so that tax sanctions will encourage taxpayers to comply.

The fourth hypothesis states that moral obligations have a positive effect on hotel and restaurant taxpayer compliance in Tabanan Regency. The results of the analysis show that moral obligations have no significant effect on taxpayer compliance. The moral obligation of hotel and restaurant taxpayers will tend to be unable to encourage hotel and restaurant taxpayers to comply with their tax obligations.

Moral obligations are internal factors of taxpayers in compliance with hotel and restaurant tax obligations. The results of this study do not confirm attribution theory. Attribution theory states that to be able to behave certain a taxpayer is driven by internal factors of the taxpayer itself. This finding does not support the study by Sanjaya (2014) who found a moral obligation influential on hotel taxpayer compliance in Denpasar City. These results also support the results of Layata's research (2014).

Understanding of hotel and restaurant taxpayers in Tabanan regency for the importance of taxes for State administration tends to be less. Taxpayers tend to disagree with the anxiety that is felt when they do not carry out tax obligations and do not feel comfortable doing tax evasion and respondent respondents do not agree that they pay hotel and restaurant taxes with full awareness.

\section{CONCLUSION AND SUGGESTIONS}

Based on the results of the analysis it can be concluded that distributive justice has a positive effect on hotel and restaurant taxpayer compliance in Tabanan district. This shows that the fairer tax base felt by general managers and hotel and restaurant owners causes taxpayer compliance to increase. Service quality has a positive effect on hotel and restaurant taxpayer compliance, meaning that the better the quality of service of the Great Revenue and Housing Service in Tabanan Regency, causing taxpayer compliance to increase.

Enforcement of tax sanctions does not affect taxpayer compliance and moral obligations also have no effect on hotel and restaurant taxpayer compliance in Tabanan Regency. These results indicate that enforcement of sanctions against hotel and restaurant taxpayers tends not to be on time, so taxpayers feel enforcement of sanctions is less assertive. This also affects the perception of the moral obligations of hotel and restaurant taxpayers tend to be less.

Suggest that it can be given to the Office of Revenue and Supreme Court in Tabanan Regency, so that it is more intensive to provide counseling and guidance to hotel and 
restaurant taxpayers, so as to increase awareness of taxpayers. If the awareness of taxpayers increases, they will obey their tax obligations.

The research model used has not been able to fully explain the variability of variable hotel and restaurant taxpayer compliance. One of these limitations can be caused by sampling not being distinguished between taxpayers who have arrears and not on hotel and restaurant taxes. Taxpayer compliance indicators used in this study are new tax reporting compliance and tax deposit compliance not yet up to tax calculation compliance, this is due to tax calculation compliance data must wait for the results of tax audits by the Office of Revenue and Regional Administration of Tabanan Regency.

\section{REFERENCES}

1. Ajzen, Icek. 2002. Constructing a YBP Questionnare: Conceptual and Methodological Considerations. September (Revised January, 2006)

2. Albari, 2008. Pengaruh Keadilan Terhadap Kepuasan and Kepatuhan Wajib Pajak. Jurnal UNISIA. Vol. XXXI No 69 September 2008. Hal: 280-293.

3. Ardani, Mira Novana. 2010. "Pengaruh Kebijakan Sunset Policy Terhadap Kepatuhan Wajib pajak (Studi Kasus Di Kanwil Direktorat Jendral Pajak Jawa Timur I Surabaya)" (tesis). Semarang: Magister Ilmu Hukum Program Pasca Sarjana Universitas Diponegoro.

4. Budhiarsana, I Wayan. 2015. "Pengaruh Keadilan Distributif and Penegakan Sanksi pada Kepatuhan Wajib Pajak Hotel and Restoran dengan Kepuasan wajib Pajak Sebagai Variabel Pemoderasi" (tesis). Denpasar: Universitas Udayana.

5. Chau. Gerald. Leung, Patrick. 2009. A critical review of Fischer tax compliance model: Aresearch Synthesis. Journal of Accounting and Taxation Vol.1 (2), pp, 0-34-040. Hong Kong: School of Accounting and Finance, the Hong Kong Polytechnic University, Hung Hom, Kowloon.

6. Faudi, Arabella Oentari and Yeni Mangonting. 2013. Pengaruh Kualitas Pelayanan Petugas Pajak, Sanksi Perpajakan and Biaya Kepatuhan Pajak Terhadap Kepatuhan Wajib Pajak UMKM. Tax \& Accounting Review, 1(1), h: 35-42.

7. Harmawati, Nikomang Ayu. 2015. "Pengaruh Pemahaman Perpajakan, Kualitas Pelayanan, Ketegasan Sanksi Pajak and Pemeriksaan Pajak pada Kepatuhan Wajib Pajak dengan tingkat Pendidikan sebagai Pemoderasi" (tesis). Denpasar: Universitas Udayana.

8. Jatmiko, A.N. 2006. "Pengaruh Sikap Wajib Pajak Pada Pelaksanaan Sanksi Denda, Pelayanan Fiskus and Kesadaran Perpajakan Terhadap Kepatuhan Wajib Pajak" (tesis). Semarang: Universitas Diponegoro.

9. Kelly, Harold H. 1972. "Causal Schemata and the Attribution Process," in Edward E. Jones et al. (Eds.), Attribution: Perceiving the Causes of Behavior, General Learning Press, Morristown, NJ.

10. Kelly, Harold H. 1973. "The Process of Causal Attribution," American Psychologist, Vol. 28, No. 2, 107-128.

11. Layata, Sherly. 2014. Pengaruh Kewajiban Moral, Kualitas Pelayanan, Pemeriksaan Pajak and Sanksi Perpajakan pada Kepatuhan Wajib Pajak Badan. E-Jurnal Akuntansi Universitas Udayana 9.2(2014): 540-556.

12. Lubis, I. 2010. Menggali Porensi Pajak Perusahaan and Bisnis dengan Pelaksanaan Hukum. Jakarta: Gramedia.

13. Manurung, S. 2013. Kompleksitas Kepatuhan Pajak. Available from: URL:http://www.pajak.go.id/content/article.kepatuhan,pajak (cited 2014 Oct. 24).

14. Mardiasmo. Perpajakan, Edisi Revisi. Penerbitan Andi Offset. Yogtakarta. 2011. Yogyakarta: Andi.

15. Organisation for Economic Co-operation and Development (OECD). 2001. General Administrative Principles-GAP004 Compliance Measurement.Tac guidance series. Centre for Tax Policy and Administration. 
16. Robbins, S. P. and Timothy A. J. 2008. Perilaku Organisasi (Organizational Behavior). Buku I. Jakarta: Salemba Empat

17. Rosdiana, H and Tarigan, R. 2005. Perpajakan: Teori and Aplikasi. Jakarta: Raja Grafindo Persada.

18. Sanjaya, Adi Putra. 2014. Pengaruh Kualitas Pelayanan, Kewajiban Moral and Sanksi Perpajakan Pada Kepatuhan Wajib Pajak dalam Membayar Pajak Hotel. E-jurnal Akuntansi Universitas Udayana 7.1. Halaman: 207-222

19. Suartana, W. 2010. Akuntansi Keperilakuan. Teori and Implementasi.Yogyakarta: ANDI

20. Sukarma, Dwi Anggreni. 2015. "Locus Of Control sebagai Pemoderasi Pengaruh Kualitas Pelayanan and Sanksi Perpajakan pada Kepatuhan Wajib Pajak Bumi and Bangunan Perdesaan and Perkotaan" (tesis). Denpasar Universitas Udayana.

21. Tjahyono, H. K. 2008. "Pengaruh Keadilan Keorganisasian pada Kepuasan Individu and Komitmen Keorganisasian dengan Model Sosial sebagai Variabel Moderator" (disertasi).Yogyakarta: Universitas Gadjah Mada.

22. Tjiptono, Fandy. 2002. Manajemen Jasa. Yogyakarta: Andi.

23. Trisnawati, Ni Luh Mika. 2015. "Analisis Faktor-faktor yang Mempengaruhi Kepatuhan Wajib Pajak Membayar Pajak Hotel, pajak Restoran and Pajak Hiburan di Kota Denpasar" (tesis). Denpasar: Universitas Udayana.

24. Troutman, Coleen, S. 1993. "Moral commitment to Tac Compliance as Measured by The Development of Moral Reasoning and Attitutes the Fairness of Txe Tex Laws" (Dissertation). Oklahoma State University, USA.

25. Ulupui, I.G.K. 2005. Pengaruh Partisipasi Anggaran, Persepsi Keadilan Distributif, Keadilan Prosedural and Goal Commitment terhadap Kinerja Dinas. Jurnal Bisnis and Ekonomi. Vol. 9. No. 2. Hal: 98-112. 